\title{
Development of the intercaruncular areas during early gestation and establishment of the bovine placenta
}

\author{
G. J. King, B. A. Atkinson and H. A. Robertson* \\ Department of Animal and Poultry Science, University of Guelph, Guelph, Ontario, Canada \\ NIG 2WI and *Animal Research Institute, Ottawa, Canada KIA OC6
}

\begin{abstract}
Summary. Specimens were obtained from the uteri of heifers on Days 17, 18, 20 to 30 and at 3-day intervals up to Day 45 of gestation and this material was examined by light microscopy, transmission and scanning electron microscopy. A reduction in height of the uterine epithelium on Day 18 was the first detectable maternal response to the presence of the blastocyst within the lumen. The trophoblast could be preserved in contact with the uterine epithelium by Day 20 and the attachment became progressively more complex between Days 21 and 30. Attachment occurred simultaneously in the intercaruncular and caruncular regions near the embryo and subsequently spread towards each end of the blastocyst. Agranular leucocytes were present in the uterine epithelium until Day 22 but were almost totally absent in later specimens.
\end{abstract}

\section{Introduction}

The time of attachment of the bovine trophoblast to the endometrium has been reported to be as late as Day 90 (Kingman, 1948) and as early as Day 12 (Winters, Green \& Comstock, 1942). Winters et al. (1942) assumed that attachment had occurred by Day 12 since they were unable to recover intact embryos by flushing the uteri of slaughtered animals on Day 13. However, subsequent work revealed that bovine blastocysts can be recovered and successfully transferred as late as Day 16 (Betteridge, Eaglesome, Randall \& Mitchell, 1980), indicating that attachment has not occurred by this time. Leiser (1975) observed adhesion in the intercaruncular regions near the embryo by Day 20-22 and has described the subsequent spread and increase in the intimacy of attachment. A tenuous adhesion of the chorion and caruncular epithelium has been detected as early as Day 20 and the subsequent development of the placentome has been reported (King, Atkinson \& Robertson, 1980). The latter study has now been extended to the intercaruncular regions of the placenta during early gestation.

\section{Materials and Methods}

Nulliparous heifers of mixed breeding were inseminated on the day of oestrus (Day 0). Pregnant animals were killed on Days 17 and 18, on each day between Days 20 and 30 and thereafter at 3-day intervals to Day 45. One animal was slaughtered for transmission electron microscopy (TEM) on each of Days 17, 18, 23, 27, 28, 29, 30, 33, 36, 42 and 45; two animals on Days 20, $21,22,24$ and 26; and three animals on Day 25 . In these early stages, pregnancy was confirmed by location of the blastocyst. Samples of uterine tissues were also obtained from single non-pregnant animals on each of Days 17 and 18. The reproductive tract was removed immediately after exsanguination, perfused and fixed as previously described (King, Atkinson \& Robertson, 1979). 
After the initial fixation and hardening, entire placentomes and specimens from the intercaruncular region were removed from portions of the gravid horn within $3 \mathrm{~cm}$ of the embryo or from the middle of the horn if the embryo had been dislodged. A number of 1-mm blocks were trimmed from each of the specimens and subsequently prepared for light and TEM (King et al., 1979,1980 ). Occasional blocks were not post-fixed in osmium tetroxide nor block stained with uranyl acetate. Thin sections from these blocks were mounted on gold grids and stained with $1 \%$ (w/v) phosphotungstic acid (PTA) in $3.5 \%(\mathrm{v} / \mathrm{v}) \mathrm{HCl}$ according to the method described by Wooding (1980).

The gravid horns from one additional pregnant animal on Day 18 and two heifers on Day 20 were opened along the mesometrial edge and pinned, endometrial side up, on wax. The exposed surface was then rinsed 4 times at 15 -min intervals with Dulbecco's phosphate-buffered saline (Gibco 1X), pH 7.2, to remove the trophoblast and any mucous coating. The final buffer was removed by rinsing with distilled water and replaced by $3 \%(\mathrm{v} / \mathrm{v})$ glutaraldehyde in phosphate buffer $(0.1 \mathrm{~m}, \mathrm{pH} 7 \cdot 4)$. Portions of the caruncles and of the intercaruncular regions from the mid-point of the gravid horn were cut into 1-mm cubes and prepared for TEM by the procedure given above except that phosphate buffer was substituted for the cacodylate. Adjacent areas, 1 $\mathrm{cm}$ square, were removed for scanning electron microscopy (SEM). These were fixed for a further $20-24 \mathrm{~h}$ in $3 \%(\mathrm{v} / \mathrm{v})$ glutaraldehyde, washed in phosphate buffer $(0.1 \mathrm{M}, \mathrm{pH} 7.4)$, post-fixed in $1 \%(\mathrm{w} / \mathrm{v})$ osmium tetroxide in phosphate buffer $(0.1 \mathrm{M}, \mathrm{pH} 7.4)$ containing 0.3 M-glucose for $1 \mathrm{~h}$, dehydrated through a graded series of alcohols, critical-point dried and sputter-coated with gold-palladium.

The subcellular components of epithelial cells were described as apical or basal according to their proximity to the epithelial basal lamina.

\section{Results}

\section{Relationship between trophoblast and maternal epithelia}

The filamentous blastocyst was flushed from the gravid uterine horn from one heifer on Day 18 and from two on Day 20. SEM examination of the uterine surface of the Day 18 specimen revealed no visible disruption of the maternal epithelium on the surface of the caruncle or in the intercaruncular areas (Pl. 1, Fig. 1). When the same procedure was repeated on the Day 20

\section{PLATES 1 and 2}

Abbreviations: BL, basal lamina; DC, degenerating cell; FE, trophoblast epithelial cell; FG, trophoblast giant cell; Ly, lymphocyte; ME, uterine epithelial cell; MG, uterine giant cell.

\section{PLATE 1}

Fig. 1. Intact uterine epithelial surface, intercaruncular region near the middle of the gravid horn, after a Day-18 blastocyst was removed, SEM.

Fig. 2. Damaged uterine epithelial surface, intercaruncular region near the middle of the gravid horn, after a Day-20 blastocyst was removed. SEM.

Fig. 3. Typical disruption to the uterine epithelial surface caused by removal of a Day-20 blastocyst. SEM.

Fig. 4. Openings of uterine glands illustrating difference in the shape and size of epithelial cells. Disruption of luminal surface was not apparent close to the gland openings (Day 20). SEM.

\section{PLATE 2}

Fig. 5. Electron micrograph of the maternal-trophoblast interface illustrating the columnar epithelium, a degenerating cell, a maternal giant cell and two agranular leucocytes (Day 20).

Fig. 6. Electron micrograph of the interface between the chorion and maternal epithelium (Day 44). The maternal and fetal giant cells typical of this stage of gestation are present. PTA stain.

Fig. 7. Electron micrograph of an agranular leucocyte located in the uterine epithelium (Day 20). 
PLATE 1
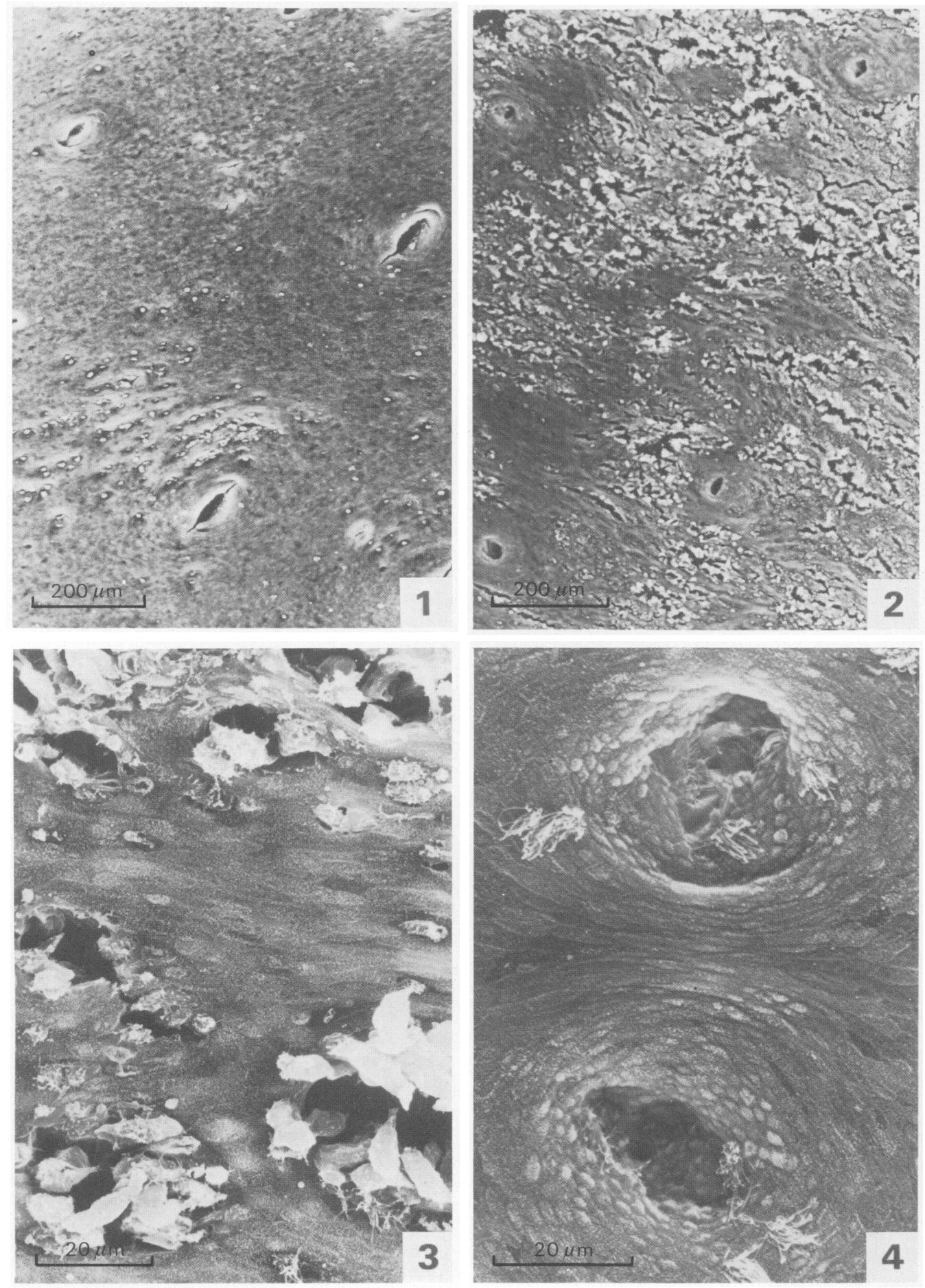

(Facing p. 470) 
PLATE 2
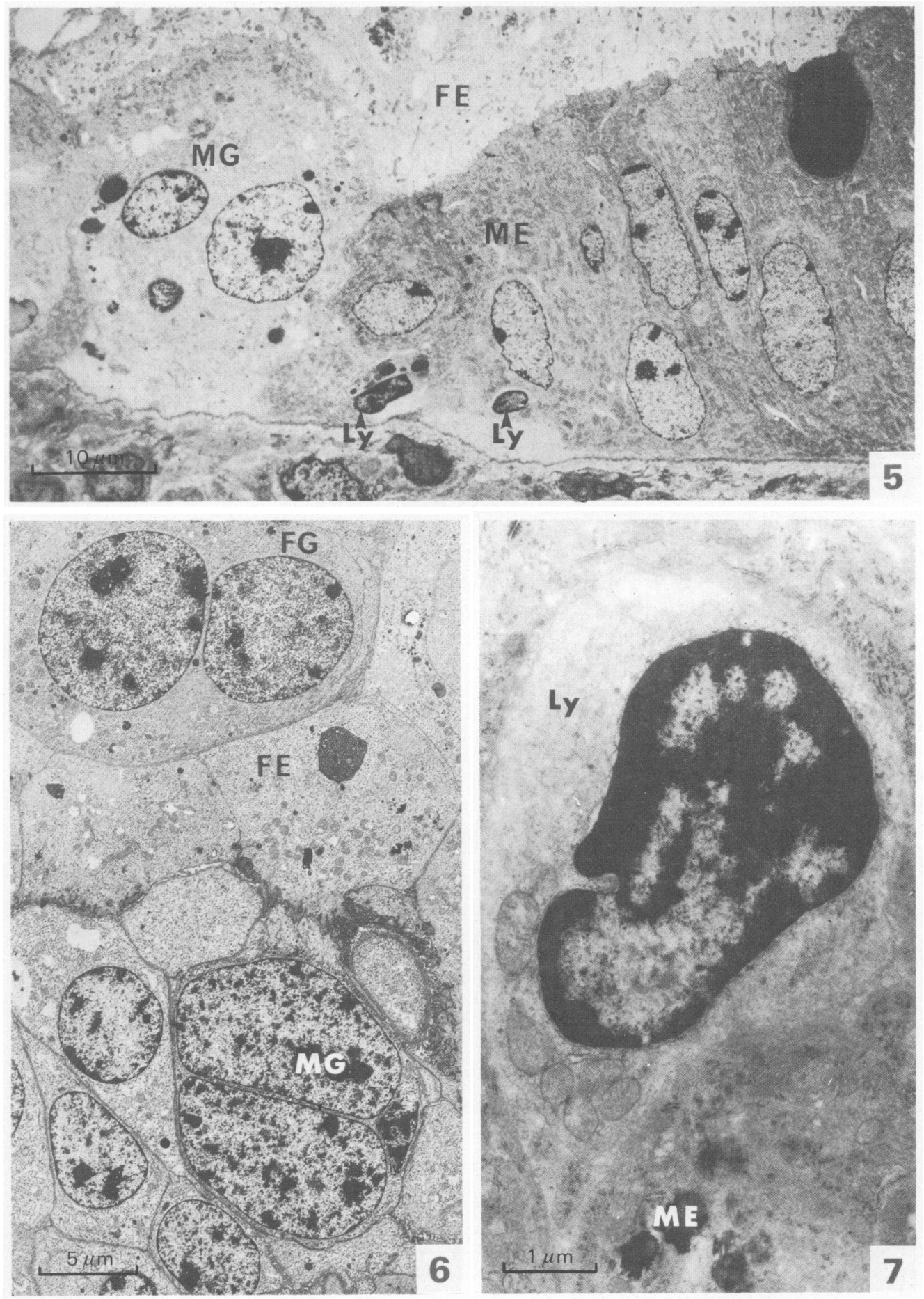
specimens, the caruncular surface and the region immediately surrounding the gland openings in the intercaruncular area were still intact, but there was some evidence of superficial damage between the gland openings. The appearance suggested that damage to the luminal membrane or complete removal of some uterine epithelial cells had occurred and/or fragments of trophoblastic tissue may have remained adherent to the epithelium (Pl. 1, Figs 2 and 3). This disruption was observed in some specimens from both animals slaughtered at this stage but the degree of damage varied from almost undetectable to extensive. There was considerable variation in the size and shape of gland openings, but the general impression was that smaller and rounder openings predominated in the 20 -day specimens.

Individual sections from plastic-embedded specimens of intercaruncular regions obtained from two other animals at Day 20 showed apposition of the trophoblast to the maternal epithelium (Pl. 2, Fig. 5). Microvilli were present on most maternal cells and some of these were indenting the apical borders of adjacent trophoblast cells. By Day 24, microvilli were present on some of the trophoblast cells and, while their presence was not uniform, those observed were interdigitating with the maternal counterparts. Extensive interdigitation was present in most specimens collected after Day 25.

\section{Maternal epithelium}

The maternal epithelium was uniformly composed of tall, pseudostratified columnar cells in both the pregnant and non-pregnant animals slaughtered on Day 17. The general appearance was unchanged in the specimens collected from a non-pregnant animal on Day 18 but cell height varied from tall to low columnar in the pregnant animal. Variation from columnar to cuboidal epithelium was observed in many Day 20 specimens but columnar regions predominated until Day 23. SEM examination of the luminal surface of the intercaruncular region confirmed this variation in cell dimension and indicated that cells with smaller apical profiles were immediately adjacent to the gland openings (Pl. 1, Fig. 4). On Days 24 and 25 some areas of flattened maternal epithelium were observed interspaced amongst predominantly cuboidal cells. Some columnar regions still persisted in the vicinity of gland openings. After Day 25 the maternal epithelium was generally composed of cuboidal cells but the presence of maternal giant cells created some irregularities in cell size and shape.

Maternal giant cells were not observed at Day 18. Between Days 20 and 23, the maternal giant cells were common, ranging from 6 to 10 per $1-\mathrm{mm}$ section. However, there was a tendency for the giant cells to occur in clumps so that the occasional section showed none. These early maternal giant cells were considerably larger than the adjacent cells, contained abundant cytoplasm and were usually multinucleated (Pl. 2, Fig. 5). All of the maternal giant cells had apical microvilli but none contained granules. After Day 25 the incidence of maternal giant cells declined but a few were present in most of the sections examined up to Day 45 . In the later stages, the giant cells were usually smaller, with little cytoplasm (Pl. 2, Fig. 6).

Small cells with single, compact nuclei containing dark clumps of chromatin and surrounded by a halo of minimal, pale cytoplasm were observed parallel to and just above the basal lamina of the maternal epithelium in the 17- and 18-day-pregnant and non-pregnant uteri. In pregnant specimens these cells could be found in most sections until Day 22 (Pl. 2, Figs 5 and 7), but were rarely observed in the specimens obtained between Days 22 and 45 . Degenerating cells were present in the maternal epithelium in all regions of the placenta from Day 20 onward (Pl. 2, Fig. 5). The maternal epithelium remained intact and no syncytium was observed in the intercaruncular regions throughout the period studied.

\section{Trophoblast}

The trophoblast was maintained in close association with the maternal epithelium at all stages from Day 20 and the general appearance was similar to that previously described in the 
placentome (King et al., 1979, 1980). Between Days 20 and 21, the proportions of giant cells in the trophoblast and maternal epithelium of the intercaruncular regions were similar and most of the trophoblast giant cells were located adjacent to regions with maternal giant cells. By Day 24, the trophoblast giant cells were common throughout the chorion and their incidence greatly exceeded that of the maternal giant cells. Many trophoblast giant cells were in contact with the maternal epithelium up to Days 25 to 27, but these had no microvilli. As gestation progressed, most of these giant cells had receded away from the interface and the incidence of granules in the basal regions increased (Pl. 2, Fig. 6).

\section{Discussion}

The earliest changes yet observed in pregnant cows are the increased secretion of progesterone by the corpus luteum from Day 10 (Lukaszewska \& Hansel, 1980) and the increased blood flow through the gravid horn around Day 15 (Ford, Chenault \& Echternkamp, 1979). An antiluteolytic factor has also been detected in bovine embryonic homogenates between Days 15 and 17 (Northey \& French, 1980). Previously, it was thought that the inhibition of luteolysis occurred considerably in advance of implantation, but the ability to preserve and demonstrate adhesion of the trophoblast to the maternal epithelium by Day 20 suggests that prolongation of luteal function and the initial stages of placentation may be very closely synchronized. Many of the physical and hormonal changes associated with this early development of the bovine conceptus have recently been reviewed by Thatcher et al. (1980).

Observations on the microscopic aspects of bovine placentation from Day 21 onwards have been reported (Leiser, 1975; Leiser \& Wille, 1975a, b) and the results of the present study are in general agreement with these. Leiser (1975) has tabulated the events occurring during early bovine gestation but we have proposed a more detailed hypothesis covering the relationship between the trophoblast and the maternal epithelium before and throughout the period when the placenta is becoming established (Table 1).

Table 1. Proposed relationship between the bovine trophoblast and uterine epithelium in the region of the embryo during early gestation

\begin{tabular}{|c|c|}
\hline $\begin{array}{l}\text { Days after } \\
\text { insemination }\end{array}$ & Interaction between trophoblast and uterus \\
\hline Up to 16 & $\begin{array}{l}\text { Embryo transfer possible (Betteridge et al., 1980) indicating that no vital interaction between the } \\
\text { trophoblast and uterine epithelia has occurred }\end{array}$ \\
\hline$>10$ & Increased progesterone from CL (Lukaszewska \& Hansel, 1980) \\
\hline $14-18$ & Increased blood flow to gravid horn (Ford et al., 1979) \\
\hline 17 & $\begin{array}{l}\text { Embryo transfer no longer possible (Betteridge et al., 1980) indicating that the conceptus is } \\
\text { necessary to maintain uterine receptivity, probably through inhibition of luteolysis (Northey \& } \\
\text { French, 1980) and possibly immunosuppression (Amoroso \& Perry, 1975) }\end{array}$ \\
\hline $17-18$ & $\begin{array}{l}\text { Apposition phase. Reduction in maternal cell height in response to presence of the trophoblast on } \\
\text { Day } 18\end{array}$ \\
\hline $18-20$ & $\begin{array}{l}\text { Adhesion phase. No superficial damage to uterine epithelium when Day } 18 \text { blastocyst removed. } \\
\text { Damage detected when Day } 20 \text { blastocyst removed. Trophoblast could be preserved in contact } \\
\text { with uterine epithelium of caruncle and intercaruncular regions on Day } 20\end{array}$ \\
\hline $21-30$ & $\begin{array}{l}\text { Attachment phase. Progressive attachment of trophoblast to intercaruncular (Leiser, 1975) and } \\
\text { caruncular surfaces (King et al., 1980). Disappearance of agranular leucocytes }\end{array}$ \\
\hline $31-32$ & Development of villi and crypts in placentomes (King et al., 1979) \\
\hline
\end{tabular}

Viable bovine embryos have been collected as late a ys 15-16 and successfully transferred to recipients who were at Day 16 after oestrus, bu: gnancies were not established when Day-16 embryos were placed in uteri of recipients at Day 17 of the cycle (Betteridge et al., 1980 ). Such results suggest that the uterus is receptive up to Day 16 , that no message or signal 
from the conceptus to the maternal system is essential before that time and that placentation has probably not begun. In the current study, when sections were obtained from the middle portion of a gravid horn and from the horn ipsilateral to the corpus luteum on Day 17 of the cycle, the specimens from both animals revealed very tall, pseudostratified columnar epithelia. When the same procedure was repeated on Day 18, the epithelium in the non-pregnant animal was unchanged, but cell height was irregular and reduced in the pregnant heifer. This change may represent an initial response of the epithelium to apposition of the trophoblast.

No evidence of disruption to the luminal surface of the uterine epithelium was observed by SEM on Day 18 after the blastocyst had been flushed from the gravid horn and specimens from the mid-portion of the horn were examined. A tenuous apposition and adhesion probably occurs in the region near the embryo between Days 18 and 20 since some epithelial surface damage was detected after Day-20 blastocysts were flushed. This conclusion was further supported by the preservation of segments of the chorion in close contact with the uterine epithelium of both the caruncular (King et al., 1980) and intercaruncular areas at Day 20. Maternal microvilli were indenting the apical surfaces of the adjacent trophoblast cells on Day 20 and the complexity of the attachment subsequently increased as microvilli developed on the trophoblast. Formation of the placenta begins in the region of the embryo and subsequently spreads towards each end of the blastocyst (Leiser, 1975).

The lymphocyte-like cells present in the maternal epithelium were ultrastructurally similar to the agranular leucocytes previously described in the rat epididymis (Hoffer, Hamilton \& Fawcett, 1973). In sections examined by light microscopy, these cells had the same general appearance as the non-granular intra-epithelial cells found in the intercaruncular regions of the ovine uterus during early pregnancy (Kellas, 1961). These intra-epithelial cells persist throughout pregnancy in ewes but are apparently transformed into granular forms as gestation progresses. The lymphocyte-like cells in early ovine pregnancy are common in regions where the the columnar surface epithelium is intact but rare or absent in areas where trophoblast is actively interacting with the uterine epithelium. In the present study, the population of agranular leucocytes was substantially reduced in the region near the bovine embryo as the intimacy of attachment between the trophoblast and epithelium increased. However, substantial numbers may still have been present in areas slightly removed from this segment of the gravid horn. Peel (1980) reported that labelled lymphocytes, injected intravenously into syngeneic rats during early gestation, could be detected in decidual tissue. However, when the same procedure was used in rats during the second half of pregnancy, no lymphocytes were observed in the uterus. Amoroso \& Perry (1975) have postulated that the trophoblast must create a barrier which prevents immunocompetent cells from reaching and damaging the embryo. The disappearance of agranular leucocytes from the uterine epithelium of the heifer as the placenta develops may be one factor in a complex protection system.

In addition to the luteotrophic (Lukaszewska \& Hansel, 1980) and anti-luteolytic (Northey \& French, 1980) properties of the early bovine embryo, there are several reports demonstrating that this blastocyst has hormone-producing abilities. Testosterone and possibly oestradiol are produced by the bovine blastocyst at Day 15-16 (Shemesh, Milaguir, Ayalon \& Hansel, 1979) and placental lactogen can be demonstrated in the conceptus by Day 17 (Flint, Henville \& Christie, 1979). Either or both of these hormone systems could be involved in the suppression of luteolysis, the initiation of placentation, prevention of immune rejection and the subsequent maintenance of pregnancy.

This is Animal Research Inctitute publication No. 942.

\section{References}

Amoroso, E.C. \& Perry, J.S. (1975) The existence during gestation of an immunological buffer zone at the interface between maternal and foetal tissues. Phil. Trans. $R$. Soc. Lond. B 271, 343-361. 
Betteridge, K. J., Eaglesome, M.D., Randall, G.C.B. \& Mitchell, D. (1980) Collection, description and transfer of embryos from cattle 10-16 days after oestrus. J. Reprod. Fert. 59, 205-216.

Flint, A.P.F., Henville, A. \& Christie, W.B. (1979) Presence of placental lactogen in bovine conceptuses before attachment. J. Reprod. Fert. 56, 305-308.

Ford, S.P., Chenault, J.R. \& Echternkamp, S.E. (1979) Uterine blood flow of cows during the oestrous cycle and early pregnancy: effect of the conceptus on the uterine blood supply. J. Reprod. Fert. 56, 53-62.

Hoffer, A.P., Hamilton, D.W. \& Fawcett, D.W. (1973) The ultrastructure of the principal cells and intraepithelial leucocytes in the initial segment of the rat epididymis. Anat. Rec. 175, 169-202.

Kellas, L.M. (1961) An intra-epithelial granular cell in the uterine epithelium of some ruminant species during the pregnancy cycle. Acta anat. 44, 109-130.

King, G.J., Atkinson, B.A. \& Robertson, H.A. (1979) Development of the bovine placentome during the second month of gestation. J. Reprod. Fert. 55, 173-180.

King, G.J., Atkinson, B.A. \& Robertson, H.A. (1980) Development of the bovine placentome from Days 20 to 29 of gestation. J. Reprod. Fert. 59, 95-100.

Kingman, H.E. (1948) The placentome in the cow. Am. $J$, vet. Res. 9, 125-150.

Leiser, R. (1975) Kontaktaufnahme zwischen trophoblast und unterusepithel während der frühen implantation beim rind. Anat. Histol. Embryol. 4, 63-86.

Leiser, R. \& Wille, K.H. (1975a) Alkaline phosphatase in the bovine endometrium and trophoblast during the early phase of implantation. Anat. Embryol. 148, 145-157.
Leiser, R. \& Wille, K.H. (1975b) Cytochemical establishment of acid phosphatase in the bovine endometrium and trophoblast during implantation. Anat. Embryol. 148, 159-173.

Lukaszewska, J. \& Hansel, W. (1980) Corpus luteum maintenance during early pregnancy in the cow. $J$. Reprod. Fert. 59, 485-493.

Northey, D.L. \& French, L.R. (1980) Effect of embryo removal and intrauterine infusion of embryonic homogenates on the lifespan of the bovine corpus luteum. J. Anim. Sci. 50, 298-302.

Peel, S. (1980) An investigation of lymphocyte movement to the pregnant uterus. J. Anat. 160, 661, Abstr.

Shemesh, M., Milaguir, F., Ayalon, N. \& Hansel, W. (1979) Steroidogenesis and prostaglandin synthesis by cultured bovine blastocysts. J. Reprod. Fert. 56, 181-185.

Thatcher, W.W., Lewis, G.S., Eley, R.M., Bazer, F.W., Fields, M.J., Williams, W.F. \& Wilcox, C.J. (1980) Contribution of the bovine conceptus to the endocrinological phenomenon existing at implantation, during gestation and around parturition. Proc. 9th Int. Cong. Anim. Reprod. \& A.I., Madrid 1, 9-22.

Winters, L.M., Green, W.W. \& Comstock, R.E. (1942) Prenatal development of the bovine. Tech. Bull. Minn. Agr. Stn No. 151.

Wooding, F.B.P. (1980) Electron microscopic localization of binucleate cells in the sheep placenta using phosphotungstic acid. Biol. Reprod. 22, 357365 .

Received 21 July 1980 